\title{
Études/Inuit/Studies
}

\section{Inuit involvement in developing a participatory action research project on youth, violence prevention, and health promotion}

\section{L'implication des Inuit dans l'élaboration d'un projet de recherche-action participative sur la prévention de la violence et la promotion de la santé chez les jeunes}

\section{Marika Morris}

Volume 40, numéro 1, 2016

La santé des Inuit

Inuit health

URI : https://id.erudit.org/iderudit/1040147ar

DOI : https://doi.org/10.7202/1040147ar

\section{Aller au sommaire du numéro}

Éditeur(s)

Association Inuksiutiit Katimajiit Inc.

Centre interuniversitaire d'études et de recherches autochtones (CIÉRA)

ISSN

0701-1008 (imprimé)

1708-5268 (numérique)

Découvrir la revue

Citer cet article

Morris, M. (2016). Inuit involvement in developing a participatory action research project on youth, violence prevention, and health promotion. Études/Inuit/Studies, 40(1), 105-125. https://doi.org/10.7202/1040147ar

\section{Résumé de l'article}

Cet article décrit le processus d'élaboration d'une recherche-action participative en partenariat entre université et communauté sur la prévention de la violence chez les jeunes Inuit par le biais des médias sociaux. Pauktuutit Inuit Women of Canada en avait choisi le sujet, défini les objectifs de recherche, rédigé en commun le premier jet de la recherche et de sa méthodologie ; constitué et présidé un comité-conseil inuit ; organisé les consultations avec d'autres organisations inuit pour en raffiner la méthodologie ; et facilité la constitution d’un groupe de discussion. La partie " action » du projet consistait à utiliser les résultats de la recherche pour développer, avec les jeunes Inuit, un média social stratégiquement orienté sur la prévention de la violence et la promotion de la santé. Cet article traite du processus de recherche tel qu'il a été guidé par l'Inuit Qaujimajatuqangit (les valeurs traditionnelles), tandis que la méthodologie était révisée par des Inuit, y compris des jeunes et des aînés. Il en a résulté un groupe de discussion de prévention de la violence pour les Inuit de 18 à 25 ans, codirigé par le Centre de guérison Mamisarvik, et un sondage en ligne au sujet de l'utilisation des médias sociaux chez les Inuit de 18 à 25 ans. Ce processus de recherche-action participative est présenté comme un modèle potentiel pour les partenariats entre universités et communautés. 


\title{
Inuit involvement in developing a participatory action research project on youth, violence prevention, and health promotion
}

\author{
Marika Morris*
}

\begin{abstract}
RÉSUMÉ
L'implication des Inuit dans l'élaboration d'un projet de recherche-action participative sur la prévention de la violence et la promotion de la santé chez les jeunes

Cet article décrit le processus d'élaboration d'une recherche-action participative en partenariat entre université et communauté sur la prévention de la violence chez les jeunes Inuit par le biais des médias sociaux. Pauktuutit Inuit Women of Canada en avait choisi le sujet, défini les objectifs de recherche, rédigé en commun le premier jet de la recherche et de sa méthodologie; constitué et présidé un comité-conseil inuit; organisé les consultations avec d'autres organisations inuit pour en raffiner la méthodologie; et facilité la constitution d'un groupe de discussion. La partie "action" du projet consistait à utiliser les résultats de la recherche pour développer, avec les jeunes Inuit, un média social stratégiquement orienté sur la prévention de la violence et la promotion de la santé. Cet article traite du processus de recherche tel qu'il a été guidé par l'Inuit Qaujimajatuqangit (les valeurs traditionnelles), tandis que la méthodologie était révisée par des Inuit, y compris des jeunes et des aînés. II en a résulté un groupe de discussion de prévention de la violence pour les Inuit de 18 à 25 ans, codirigé par le Centre de guérison Mamisarvik, et un sondage en ligne au sujet de l'utilisation des médias sociaux chez les Inuit de 18 à 25 ans. Ce processus de recherche-action participative est présenté comme un modèle potentiel pour les partenariats entre universités et communautés.
\end{abstract}

\begin{abstract}
Inuit involvement in developing a participatory action research project on youth, violence prevention, and health promotion

This article describes the process of developing an academic and community participatory action research partnership on Inuit youth and violence prevention through social media. Pauktuutit Inuit Women of Canada chose the topic, defined the research goals, co-developed the first draft of the project and its methodology, established and chaired an Inuit advisory committee, spearheaded consultations with other Inuit organizations to refine the methodology, and co-facilitated a focus group. The "action" part of the project involved using the research results to develop with Inuit youth an
\end{abstract}

* School of Indigenous and Canadian Studies, Carleton University, 51-300 Cooper Street, Ottawa, Ontario K2P 0G7, Canada. Marika.Morris@Carleton.ca 
outreach strategy to prevent violence and promote health via social media. The article discusses the research process, which was guided by Inuit Qaujimajatuqangit (traditional values) and which used a methodology redesigned by Inuit, including youth and elders. The result was a violence prevention focus group for Inuit aged 18 to 25 , co-led by the Mamisarvik Healing Centre, and an online survey of social media use among Inuit aged 18 to 25 . This participatory action research process is presented as a potential model for academic-community partnerships.

\section{Introduction}

The high rates of violence, suicide, substance abuse, and impaired mental health in Inuit communities have the same root-colonial disempowerment and intergenerational trauma (Morris and Crooks 2015; O'Neil 1986). Despite great challenges, Inuit are developing their own solutions and doing the research they need to form the evidence base for action. Academics can support these efforts by approaching Inuit organizations about research they could contribute to. Such efforts were documented by Nickels and Knotsch (2011) with respect to Inuit Nipingit (National Inuit Committee on Ethics and Research), which was established in 2008. Its members were drawn from the national association Inuit Tapiriit Kanatami (ITK), from each regional Inuit land claims organization, and from some other Inuit organizations, including Pauktuutit Inuit Women of Canada. From 2008 to 2010, Inuit Nipingit worked to provide input into the revision of the Tri-Council Policy Statement: Ethical Conduct for Research Involving Humans (CIHR et al. 2010) and stressed the need to bring Inuit into every stage of research:

Some Inuit are concerned about the conduct of research and about the community impacts. Some of the concern stems from lack of consultation in identifying research needs and questions and in designing studies. Inuit often feel they are not adequately involved throughout the research process (e.g., project design, data collection and analysis, and communication of results)

(Nickels and Knotsch 2011: 64).

Nickels and Knotsch (2011) praised the second edition of the Tri-Council Policy Statement (TCPS2) but raised doubts about the ability of academic researchers to live up to guidelines for true community engagement at every stage of research, including the very first stage, due to academic and research funding structures. In their interviews with 20 community-engaged researchers working with Indigenous communities in Canada, Castleden et al. (2015) confirmed that there is still a disconnect. On the one hand, academic funding is subject to ethical guidelines and institutional expectations. On the other, Indigenous communities are not yet fully involved in every stage of research. Nor do they yet have full power to change the research questions and approach.

If research is not conducted respectfully and collaboratively, it can become just another aspect of colonization (Smith 1999). Research on Inuit has sometimes 
been conducted in disempowering and non-inclusive ways (Nickels and Knotsch 2011). Inuit Nipingit identified the following as some of its primary concerns (Nickels and Knotsch 2011: 62-63):

- community empowerment (i.e., balancing powers between researchers and communities, communities to share in the benefits of research);

- effects on communities and regions (i.e., increasing positive outcomes and reducing negative ones);

- knowledge sharing between researchers and individuals, communities, regions, and governments (i.e., engaging in meaningful communication $[\ldots]$ ) [...]

Inuit Nipingit felt it essential to promote the principle of "relationship" in research with Inuit communities.

A participatory action research (PAR) model is the best fit for Inuit Nipingit's concerns, in that it prioritizes relationship building, empowerment, and knowledge sharing and seeks to create positive outcomes. There are many definitions of PAR, a reflection of its use in a multiplicity of fields (sociology, anthropology, social psychology, philosophy, public health, women's studies/ feminist research, and community-based research). MacDonald (2012) explained that PAR is a subset of action research, the goal of which is to make a specific change, and not just to produce research. It is research in which "research participants (called "subjects" in traditional research) decide the research objectives, research question, research methodology, [and] are involved in data collection and analysis" (Morris and Muzychka 2002: 10). In their exploration of the use of PAR in public health, Baum et al. (2006: 854) stated that "PAR seeks to understand and improve the world by changing it [...]. The process of PAR should be empowering and lead to people having increased control over their lives [...]." Brydon-Miller et al. (2011) elaborated that PAR is a collaborative process embedded in understanding broad social, economic, and political forces and aimed at using research to solve community problems. They added that "PAR is responsive to changing circumstances, adapting its methods, and drawing on the resources of all participants to address the needs of the community" (BrydonMiller et al. 2011: 387).

Most PAR definitions agree on one thing: information should be gathered in ways that empower the marginalized and which support actions to improve their situations. In this sense, PAR is well-suited for research with Indigenous peoples, who have traditionally been objects of research while having little control over research topics, methods, analysis, or communication and use of the results (McTaggart 1991). It has developed as a challenge to conventional research practices, which research participants view as a tool of colonization (Kemmis and McTaggart 2000). Indeed, PAR changes the relationship between society and knowledge, which the powerful have traditionally generated, interpreted, and benefited from (Fals Borda 2001). 
This article is about a relationship-based process-the collaborative, participatory, and engaged research process of the Makilirit research project, an academic-community partnership. The project itself resulted in new knowledge on how to prevent violence among Inuit youth and how they use social media (Morris and Crooks 2015). It also provided several insights into the way research is done: what worked well and what did not in the PAR process; how the research design was constructed in partnership with an Inuit organization; how it was completely transformed through further consultations with Inuit youth, organizations, and healers; and how it may be used as a template or a guide for other academic researchers working with Inuit.

\section{Partnership process}

Pauktuutit Inuit Women of Canada works on violence prevention, health promotion, and socioeconomic development, among other issues. Pauktuutit is governed by a Board of Directors of 15 Inuit with representation from Inuit Nunangat (i.e., all Inuit regions: Nunatsiavut in Labrador, Nunavik in Northern Quebec, Nunavut, and the Inuvialuit Settlement Region of the Northwest Territories), urban Inuit, and youth. One of its aims, since it was established in 1984, has been to eliminate violence against Inuit women and children. To this end, it has produced public education materials, worked through schools in the North, supported Inuit women's shelters, hosted community meetings, distributed materials, and created radio and TV outreach (e.g., Pauktuutit 2004, 2005, 2006, 2011, 2013a, 2013b).

Many Inuit, especially young people, are moving to southern Canada and are harder to reach with these methods. According to Statistics Canada's latest counts, over a quarter of the Inuit population (27\%) now live outside Inuit Nunangat (Statistics Canada 2015). Youth are a key demographic in Inuit communities. In fact, the population structure is much younger than that of most other groups in Canada: in 2015, 54\% of Inuit were younger than 25 versus only $30 \%$ of non-Indigenous Canadians (ibid.). Aware that many Inuit youth use Facebook, Pauktuutit wanted to find out whether social media would be an effective method to reach them and wanted data to develop a social media campaign aimed at Inuit youth on violence prevention.

The author is an experienced community-based researcher who returned to university later in life to earn a Ph.D. in 2010. She had previously worked as research coordinator of the Canadian Research Institute for the Advancement of Women and as a research consultant. In the latter role, she worked with Pauktuutit on a number of projects, including research and action on child sexual abuse and violence against women. Her personal relationship with some Pauktuutit staff dates back 25 years to research with the Canadian Panel on Violence Against Women.

Once the author's Ph.D. was completed, she had a five-year window of opportunity to apply for a postdoctoral fellowship. Motivated to do research that 
would benefit Inuit, she approached her existing contacts at Pauktuutit. This resulted in a two-hour meeting at which the Pauktuutit Executive Director, the Manager of Health Policy and Programs, and the Abuse Prevention Manager outlined what research the organization would like to do if it had the capacity and funds. The author took a four-page list away of potential projects, which were later examined against the criteria for a Canadian Institutes of Health Research (CIHR) or Social Sciences and Humanities Research Council (SSHRC) postdoctoral fellowship. These fellowships provide a stipend for one researcher, with a small research budget. Among the possible research topics identified at the meeting, many did not meet the fellowship criteria because they would require either an extensive budget for travel throughout the Arctic or more than one researcher. Finally the author found three topics that met the criteria. She developed her ideas for research and met again with Pauktuutit to present them.

Of these topics, Pauktuutit gave priority to violence prevention among Inuit youth through social media. This was fortunately one of Pauktuutit's original priorities on the four-page list. At that time, the goals were to:

- Document sexual and physical violence and its impact on Inuit children and teenagers, ${ }^{1}$ primarily in Ottawa [due to budget constraints];

- Ask about mechanisms Inuit have used in their childhood or teenage years to cope with violence;

- Discover what messages Inuit youth receive about violence from family, friends, and communities;

- Find out how much young Inuit use social media, particularly Facebook;

- Ask young Inuit for advice about how best to reach Inuit youth;

- Respect the research participants and affirm that their lives have value, and ensure that their knowledge about their own lives is respected;

- Share resources about violence and about how and where one can seek help when dealing with issues of violence; and

- Create an evidence-based outreach strategy to prevent violence among Inuit youth via social media.

Once Pauktuutit chose the research project and co-developed the research goals, the author set about finding an appropriate academic supervisor (as required for postdoctoral fellowships): Dr. Claire Crooks. At that time she was at the Centre for Addiction and Mental Health (CAMH) in Toronto. She later moved and became an Associate Professor and Director of the Centre for School Mental Health at the Faculty of Education at Western University in London, Ontario. Dr. Crooks had extensive experience working on violence and health issues with Indigenous youth. She supervised from a distance because the

1. The original age range was 17 to 24 . It was changed to 18 to 25 in order to avoid any consent issues for persons under 18 . 
postdoctoral fellow was already an experienced community-based researcher who had worked with Indigenous organizations on issues of violence prevention. She displayed respect for both the postdoctoral researcher and the community research partner, and encouraged rather than directed. The research proposal was thus developed by Pauktuutit and the author, with the input of Dr. Crooks, the original aim being to conduct interviews with youth. The research was funded by a postdoctoral fellowship of the CIHR Institute of Aboriginal Peoples' Health.

Pauktuutit is experienced with research projects, having both initiated its own research and participated in research partnerships with academics. In this role, it establishes and chairs an advisory committee of Inuit and people working in Inuit agencies, asks appropriate people to name the project in Inuktitut, and develops guiding principles for the project. It prefers developing or co-developing research proposals before they are submitted to grant application and/or academic research ethics boards. Pauktuutit's established research process was followed for this project.

Pauktuutit set up an advisory committee and appointed representatives from the Ottawa Inuit Children's Centre, from Embrace Life (a suicide prevention organization in Nunavut), and from Qullit Nunavut Status of Women Council. Another committee member was a researcher who had done work on violence and human trafficking of Inuit. Inuit Tapiriit Kanatami and the Nunavut Research Institute (2007) published a document to provide researchers with clear guidance on how to interact with Inuit communities. This valuable guide assumes the researchers will be located in a northern Inuit community and engaging with the population there. The project targeted Inuit youth throughout Canada, including urban areas. Project members did not physically go into any community, apart from Ottawa. Therefore other methods of engagement were necessary to ensure Inuit participation. Adequate youth representation on the advisory committee was essential, so the Pauktuutit project lead suggested a postdoctoral researcher and arranged for this person to engage students from Nunavut Sivuniksavut, a college program in Ottawa for Inuit from Nunavut. The students would be Inuit 18 to 25 years old.

In early 2014, Pauktuutit staff and the postdoctoral researcher made a presentation to first-year Nunavut Sivuniksavut students to introduce the project, to encourage their participation on the advisory committee, and to invite them to name the project in Inuktitut. After describing the project in plain language, the original project title was shown on the screen: "Inuit knowledge translation: Community-controlled, culturally-sensitive research with Inuit youth on experiences with violence, health effects and coping mechanisms, engaging Inuit youth in developing a research-based, health promotion campaign on issues of violence using social media." The students laughed. This was perhaps their first experience with a rather convoluted research title. A Pauktuutit staff-person engaged the students in Inuktitut and wrote down their suggestions for a project name in Inuktitut. As a result of the students' input, the project was simply 
named Makilirit ("Rise up"). At the end of that first meeting, five students signed up to sit on the advisory committee.

\section{Inuit values, research ethics, and guiding principles}

Guiding principles explicitly incorporating Inuit Qaujimajatuqangit (Inuit societal values) or IQ were developed. There are regional variations of IQ, but it was decided to use values from the work of Inuk elder Pelagie Owlijoot, as codified by Nunavut Arctic College (Owlijoot 2008). Participatory action research principles and IQ have in common an emphasis on relationship, inclusion, being of service (committed to positive action), discussion and consensus among participants, learning and skills-building (not just for the researcher), and working together to deal with challenges as they arise. Outlined below are the project's guiding principles, with the elements of IQ in bold:

1) All Inuit and other people of the world should be safe and free from violence.

2) This is not just a research project, but also an action project to help prevent violence against Inuit.

3) Young Inuit can be leaders in preventing violence.

4) We will conduct this research in keeping with the funder's ethical guidelines and requirements.

5) We will base the project on Inuit Qaujimajatuqangit. The project will respect the principles of Inuit Qaujimajatuqangit in the following ways:

\section{Inuuqatigiitsiarniq: Respecting others, respecting relationships, and caring for people}

We will be respectful toward one another on the advisory team, and respectful toward all those who participate in the research. We will ensure that all advisory team members and research participants are aware of resources they can turn to if participation in this research project triggers feelings associated with their own experiences with or witnessing of violence. Should the interviews take place only in Ottawa, we are confident in the readiness of this community. There are services available to Inuit in Ottawa, and violence is already discussed in Ottawa. Should there be another location added to the research, we would have to look at the readiness of that community for a project that might increase demand for services for survivors of violence.

2. Tunnganarniq: Fostering good spirit by being open, welcoming, and inclusive

We will approach this project with open spirits. We will reach out to Nunavut Sivuniksavut students to name the project and become involved. We will welcome research participants and let them know how appreciated 
they are. We will hold the interviews in a place where they can be comfortable. We will offer research participants the choice of doing the interview in Inuktitut or English. We will ensure participants benefit from participating because, without them, there would be no project. They are the experts on their own lives.

\section{Pijitsirniq: Serving and providing for family and/or community}

The purpose of this project is to help reduce violence in Inuit communities. All Inuit deserve to be happy and safe. We hope this project will serve Inuit well as an opportunity to share experiences with violence, to learn about resources, and to use creativity to reach out to other Inuit about violence prevention. The goal is to develop an outreach strategy to help prevent violence among Inuit youth via social media.

\section{Aajiiqatigiinniq: Decision making through discussion and consensus}

We have gathered young people, elders, professionals, and members of organizations together because we each have a valuable perspective to contribute. We all have different lives and differing amounts of time and interest in each project component, and we understand that people will contribute when they can. We recognize that the goal of this project is to gather information that will help Pauktuutit develop an outreach strategy to prevent violence among Inuit youth via social media, and our decisions will reflect this purpose.

\section{Pilimmaksarniq/Pijariuqsarniq: Developing skills through practice, effort, and action}

We are hoping to learn from this project, not only by gathering knowledge about violence, but also by improving our skills in listening, in information gathering, and in communicating.

\section{Piliriqatigiinniq/Ikajuqtigiinniq: Working together for a common cause}

We are all committed to ending violence in Inuit communities and the world. This project is one step of many, many steps in that direction.

\section{Qanuqtuurniq: Being innovative and resourceful}

During the course of this project, we may experience challenges. Things may not go as expected. We are resourceful and committed to resolving whatever problems arise.

\section{Avatittinnik Kamatsiarniq: Respecting and caring for the land,} animals, and the environment

We will operate mainly by telephone, emails and meetings, and not with a lot of printed paper, in order to reduce the impact of our project on the environment. 


\section{Methodology development and ethics review process}

To apply for postdoctoral funding and to have an ethics review carried out by the hosting institution, one has to have a defined research project. However, in participatory action research, the research questions and design should ideally be set by the research participants or the target group of the research, and one must always be open to project change (Morris and Muzychka 2002). In the present case, the research topic was chosen by Pauktuutit, and the researcher developed the initial proposal in conjunction with Pauktuutit's Abuse Prevention Manager. Then, the researcher applied for CIHR funding.

The CIHR proposal specified that Inuit between the ages of 18 to 25 would be interviewed about their experiences with violence and its impact, their coping mechanisms, their awareness of messages of violence, their use of social media, and potentially effective social media messaging to youth about violence prevention. It also contained a number of key phrases that would allow for changes to be made by Inuit advisors. An example is that the research would be "Inuit-controlled" and conducted fully as participatory action research in which the researcher would "work with the Inuit advisory team to develop an appropriate research plan and instruments." ${ }^{2}$

After funding was offered, the original institution hosting the postdoctoral fellowship - the Centre for Addiction and Mental Health (CAMH) at the University of Toronto-required immediate submission of an application to their Research Ethics Board (REB) in order to get permission to carry out a project on human subjects. However, the underlying assumption of the research ethics template was that the research would involve medical treatment intervention, this being not the case with the present project. The research supervisor asked for permission to delay submission of the ethics application to the REB until the Inuit could be consulted about the methodology and research instruments. CAMH agreed. However, that year the research supervisor accepted a new position at Western University, and the postdoctoral researcher moved with her.

Before going through the Western University research ethics review, the postdoctoral researcher spent one year gathering input from Inuit and relevant Inuit organizations. She extensively reviewed the literature about violence-its effects, coping mechanisms, statistics, other materials about Inuit and violence, and Inuit government or organization violence awareness and prevention campaign efforts. This research was summarized in a plain language consultation document and distributed to the project's advisory committee and to those who would provide additional input. The researcher also developed a draft research instrument (a rather lengthy interview protocol) in conjunction with Pauktuutit and sent it to the project's advisory committee for review.

2. Research instruments are used to collect data (e.g., interviews, surveys, etc.). 
Some of the advisory committee members were very active and provided direct input into the research plan. Others were never able to participate in a teleconference meeting or were preoccupied with their own duties and responsibilities and did not have time to respond to written requests to review documents. This was a major setback because one of these members represented the Ottawa Inuit Children's Centre (OICC) and two others were Nunavut Sivuniksavut students; these people were the ones most needed to shape the research, as they had a great deal of experience with Inuit youth or were part of the target group (Inuit aged 18 to 25). The postdoctoral researcher and Pauktuutit dealt with this setback by making personal visits. Pauktuutit set up a face-to-face meeting with the OICC representative to go over the research plan and interview protocol. The OICC representative ran an Inuit youth group, and one of her major concerns was online safety for Inuit youth. This was also a concern for Pauktuutit, which had launched an I'm Happy Because I'm Safe campaign to raise awareness among Inuit parents, children, and youth about online safety. As a result of the personal consultation with the OICC member, questions on this point were added to the interview protocol.

Pauktuutit also arranged a second, more in-depth consultation with Nunavut Sivuniksavut students during class time. The project was originally presented to first-year students and named by them in early 2014. By the second consultation in the fall of 2014, they were now second-year students-and their curriculum included a class on how to conduct research. The Makilirit project provided students with a practical example of how to use their knowledge and develop practical skills in research design. The hour-and-a-half consultation went through every line of the interview protocol and dealt with everything from the appropriateness of the topic to whether Inuit youth would properly understand the wording of the question. This consultation resulted in significant changes to the protocol.

One issue had kept arising since the beginning with the Pauktuutit Abuse Prevention Manager. It was the extent to which the research was focusing on the problem and not on the solution. The research instrument was very blunt about experiences with physical, sexual, and psychological violence and its effects. This focus made almost all of the Inuit who provided input into the research uncomfortable. Pauktuutit suggested a consultation with counsellors from Mamisarvik Healing Centre, one of only two Inuit-specific treatment centres in Canada. Mamisarvik deals with the aftermath of trauma: addictions and other unhealthy coping mechanisms due to the trauma of violence and residential schools, and to the effects of colonization (removal of decision-making power, loss of control, racism, shame).

The Pauktuutit Abuse Prevention Manager and the postdoctoral researcher met with two Mamisarvik staff, one of whom was also an Inuk elder. They reviewed the research plan and instrument in detail. Mamisarvik staff were likewise uncomfortable with the questions about violence and its effects because a researcher would be asking these questions and the interviewees would have no 
emotional support, even though the interviews could take place at Mamisarvik, where counsellors were available. Mamisarvik staff were able to articulate the reason for the discomfort that many of the other Inuit advisors felt: Inuit are a highly traumatized population. Many Inuit are continually reliving trauma every time someone they know commits suicide. They hear about Inuit violence and socioeconomic bad news, and the ongoing focus on problems can lead many to feel a sense of hopelessness and despair. Inuit already know what the problems are, but they need to know more about what the solutions are. Mamisarvik staff suggested a completely different research design. Instead of individual interviews, why not collect the information in a culturally safe, emotionally supported way, and focus on understanding violence, coping mechanisms, and solutions?

The Mamisarvik consultation led to a complete redesign of the research. In the original proposal, a Qallunaat (non-Inuk) researcher would interview Inuit youth for 45 minutes in detail about their experiences with violence and their social media use and how the latter could help the former. Upon reflection, the proposed small-scale study of 20 to 40 Inuit youth in Ottawa was considered an inefficient means to provide good quality information about the nature and degree of violence. Such information had already been gathered in a number of ways by Statistics Canada (2010, 2015), the Inuit Health Survey (Galloway and Saudny 2011, 2012), and interviews with 108 Inuit women from Nunavik (Laneuville 2015). The original methodology was scrapped in favour of a twopart research project:

1) an online survey of Inuit aged 18 to 25 about their social media use, with questions that were designed to meet the knowledge needs and interests of Inuit agencies and which tapped into the expertise of Inuit youth on what kinds of questions would work and how these questions would be understood; and

2) a violence prevention focus group of Inuit aged 18 to 25, which would be led by Inuit facilitators, held at an Inuit agency, and co-developed by counsellors from Mamisarvik Healing Centre, an Inuit-specific treatment centre.

Cultural and emotional safety was of paramount importance, so the leadership of trained Inuit counsellors and facilitators was key. With two Mamisarvik counsellors, the researcher and Pauktuutit developed a culturally appropriate framework for a focus group. In particular, an education component on violence prevention would be interspersed with the research questions. Now that the methodology and research instruments had been redesigned and finalized by Inuit, the Makilirit project was ready to undergo the research ethics review by the postdoctoral fellow's university. The Western University NonMedical Research Ethics Board had few revisions to recommend. Perhaps it was clear that the project had been well-thought out by Inuit for Inuit and that it also met the Tri-Council Guidelines. 
The academic advisor found some additional funds to pay Mamisarvik staff to develop the segment on violence prevention education, to recruit participants, to rent space, and to provide food and bus tickets. The focus group began with a welcome, introductions and an Inuk elder ceremonially lighting the qulliq, a traditional oil lamp. Apart from introductory and concluding activities, there were four main segments: understanding violence, coping with violence, preventing violence, and what Inuit youth should know about violence. Each segment opened with questions and answers, which were facilitated by Pauktuutit's Abuse Prevention Manager and recorded by the researcher. For example, for the "understanding violence" segment, questions included: "How common is violence in Inuit homes and communities?" "Why do you think violence happens?" The aim was to measure what the Inuit in the target age group already knew about violence and how they understood it. The data collection segment was followed by a culturally appropriate education segment led by Mamisarvik on "Types of violence. Factors that lead to violence in Inuit communities." Similarly, the other segments started with data gathering, followed by Mamisarvik talking about violence prevention education. The education segment built on the research segment. There were several positive results: gathering of new research knowledge, an Inuit template for violence prevention focus groups, and what research participants described as a great experience with information that they could take forward, apply to their lives, and talk to others about. The underlying objective was always to empower Inuit youth and support Inuit youth leadership.

\section{Factors for success}

This section outlines the lessons learned from the participatory action research process of the Makilirit project. These lessons may be used to inform development of research with Inuit.

\section{Pre-existing relationship}

It was very useful that the Makilirit researcher had a pre-existing relationship of trust with the Inuit community partner Pauktuutit. Nickels and Knotsch (2011: 63) noted that "Inuit see research as relationship development, where trust is built over time [...]." For researchers who do not already have a pre-existing relationship of trust, we recommend that they find for their research team someone who can bridge that gap, or that they begin the process of reaching out to Inuit organizations and sharing research information that may interest them.

\section{Building the relationship}

Nickels and Knotsch (2011) recommended that researchers spend informal time with Inuit research partners, and not just get down to the business of designing research. The postdoctoral researcher worked out of the Pauktuutit 
office two days per week. She and Pauktuutit staff could thus spend informal time together as well as draw on one another for a two-way exchange of skills and knowledge. She was able to draw at any time on the skills, knowledge, and experience of Pauktuutit's Abuse Prevention Manager, who made herself very available, and the researcher also helped Pauktuutit edit their funding applications. Time was spent playing cards together in the kitchen during lunchtime, thus allowing everyone to feel comfortable with one another.

\section{The Inuit organization chose the research topic}

Academic researchers have typically approached Pauktuutit for partnership after having already made decisions about the research proposal and after its approval by the research ethics board of their institution. This is too late in the process for involvement of an Inuit organization/community as a partner because the latter often has limited capacity and funds to conduct its own research and because the proposed project may not reflect its research priorities. Once the research ethics approval is received, it may be too difficult or time-consuming to modify the project, as any substantial change must go through the research ethics board again.

\section{Youth involvement}

A major factor for success was the involvement of Nunavut Sivuniksavut students during two class times. The project was named, the research instruments were shaped, and students were recruited to sit on the project advisory committee. Inuit youth thus shaped a project about Inuit youth.

\section{Involvement of Inuit healers and elders}

Without Mamisarvik Healing Centre staff, the Makilirit project would have looked completely different. Their knowledge and sensitivity about Inuit trauma shaped the research setting and instruments.

\section{Outreach included media coverage}

The online portion of the research went well because of media coverage in the North: broadcasting of a CBC Radio interview in Nunavut, online publication of an article in Nunatsiaq News with a link to the survey, wide distribution through the networks of Pauktuutit and some of the advisory committee members, and promotion of the survey on Facebook and Twitter. As well, some of the project research funds were spent on Facebook and Twitter advertising. The Facebook advertising was more successful because Inuit aged 18 to 25 could be directly targeted, and these posts were liked and shared. On Twitter, agerange targeting was impossible, and the ads just appeared to people who mentioned "Inuit" in their tweets. 


\section{Visibility of Inuit in leadership roles}

The violence prevention focus group was facilitated by Pauktuutit's Abuse Prevention Manager who was a young Inuk woman. The part on violence prevention education was led mainly by an Inuk elder who was the co-founder of Mamisarvik Healing Centre and had been Treatment Coordinator there for 13 years. Her work was supplemented in parts by the Mamisarvik Executive Director. The two co-facilitators used flipcharts, and the researcher recorded the data on smaller grids approved by the Inuit partners and her university's research ethics board. Inuit were clearly in the leading role during the focus group session, and this pre-eminence helped build trust among the research participants.

\section{Culturally safe space}

The Makilirit project also succeeded because the violence prevention focus group was held on the premises of Tungasuvvingat Inuit, a well-known and culturally safe Inuit agency based in Ottawa. The room was bright and surrounded by Inuit art and cultural touchstones. Food was another factor for success. Although it would have been nice to offer country food, none was available at the time, so there was pizza, snacks, fruit juices, and pop. Offering food at the beginning and throughout contributed to a relaxed and safe atmosphere.

\section{Inclusion of cultural practices}

After going over the consent letter, the violence prevention focus group began with the ceremonial lighting of the qulliq, which was used as an educational tool to set the stage for the group. The qulliq is a stone bowl with the fluff of Arctic cotton (suputi in Inuktitut) arranged on one side. Traditionally seal or whale oil was used. The elder who co-facilitated the focus group explained how, as a little girl, she had lived in a traditional Inuit qamaq ${ }^{3}$ and did not know that anyone else in the world existed apart from the ten families in her camp. The qulliq was their only source of heat, light, water in the winter (i.e., snow was melted for drinking water), and cooking. To make this key tool for Inuit survival, one had to know the land in order to harvest the right plants at the right time of year. The elder also took the opportunity to explain her own life journey: her contact with the Qallunaat way of life; her descent into trouble with addictions and violence; and her re-emergence and recovery. Participants were moved by the ceremony and story. They asked her questions, mainly about how to balance the Inuit and Qallunaat ways of life. The elder shared her wisdom and experience and talked about cultural support services available to Inuit in Ottawa.

3. A qarmaq (plural: qarmat) is a traditional Inuit house. It was used until the 1950s, being usually made from a framework of large animal bones, with a base of stone, sod, or snow blocks and an upper portion of skins or canvas. Igluit (plural of iglu) were neither possible nor preferred at some times of the year. 


\section{Establishing group rules and explaining the consent letter}

Because the focus group dealt with violence and because some participants could potentially disclose their own experiences, the focus group moved to the topic of group rules and confidentiality. There was agreement among the participants to listen to each other without judgment and without interruption and keep what each participant said confidential. The researcher reviewed the consent letter and answered questions before participants signed it.

\section{Presence of support}

There were other factors for success: availability of counsellors and an elder if any participants were triggered by the topic and wished to talk; and distribution to participants of flyers about resources available in Ottawa and nationally for Inuit, for youth, and for survivors of violence.

\section{Limitations}

Other factors limited the Makilirit project-its scope and reach and the effectiveness of the research process. The responses to these challenges are described below.

\section{Lack of funds}

Funds were the principal limitation. The Nunavut Sivuniksavut students had recommended that the interviews take place in all Inuit regions, but there was no money to travel to Inuit communities or to recruit others to organize focus groups. Some suggested long-distance phone interviews, but counselling might have been unavailable to youth if needed, and this option was no longer viable once the research design changed from an interview format to a focus group format. NS students had also recommended that the research materials be translated into every dialect of Inuktitut, Inuinnaqtun, and Inuvialuktun, but the costs would have been prohibitive. Pauktuutit's experience was that most Inuit youth speak English and get their school education in that language. Indeed, Statistics Canada data confirm that Inuit languages are declining among many Inuit youth, except in Nunavik (Wallace 2014).

The partner organization, Pauktuutit, was experiencing funding difficulties at the time of the Makilirit project because policy and funding priorities were being changed by the federal government, then led by Prime Minister Stephen Harper. The organization thus had to lay off staff but was still responsible for meeting goals despite reduced resources. As such, it did not have much in the way to contribute to the project other than the valuable time of the Abuse Prevention Manager, who was also juggling numerous other projects. There were long gaps between advisory committee meetings, and these meetings were eventually discontinued and replaced by face-to-face consultations. 


\section{Advisory committee did not gel}

Although Pauktuutit regularly staffs advisory committees with Inuit and with people from Inuit organizations for its projects, this approach was inadequate for the Makilirit project. Because of their disparate locations, committee members met by teleconference and communicated by email. They included adult professionals as well as Inuit youth. Members had other jobs or studies, and some also had family responsibilities or many other priorities. Two out of five of the youth members provided direct input into the project, but only as emails sent directly to the researcher-they did not reply to the group, perhaps because they had never met all its members and may have felt uncomfortable. One member of the advisory committee provided consistent feedback every time the group was asked for input. Another member provided input only when we met with her face-to-face; such meetings could be arranged because of her location. Two others provided input from time to time.

The researcher and project lead came to rely on direct face-to-face input from Inuit stakeholders, rather than continuing to convene advisory committee meetings. The dynamics between individuals and various agencies on a committee could influence their level of participation. Due to the low level of input from some of the Inuit youth on the advisory committee, it was decided to seek participation from a larger group of Inuit youth, the Nunavut Sivuniksavut students. This approach was much more successful than either teleconference calls or email input. Had there been adequate funds, face-to-face meetings with advisory committee members would have been convened, thus bringing members in from across Canada.

\section{Getting youth to the focus group}

At the end of the violence prevention focus group meeting, Inuit youth participants talked about what a great experience it had been. They lingered at the end, not wanting to go even after it was over. However, getting Inuit youth to the meeting was a problem. Four youths who had signed up did not arrive. Mamisarvik counsellors, who had arranged for their participation, followed up by phone. The focus group meeting was held on a Saturday in June when the weather was beautiful and when free festivals were going on in the city. Unfortunately, the focus group meeting was limited to that date because many partners had scheduling conflicts on other dates and because the funding had to be spent by the end of June.

\section{Lengthy, legalistic consent letters}

The consent letter was explained in detail to the participants before the violence prevention focus group began its meeting. For example, because discussions could potentially elicit disclosures, the consent letter included a warning that the researcher would have to violate confidentiality and report to the authorities any suspicion of child abuse. One woman left after reading the 
consent letter, as it changed her mind about participating. Her action demonstrated that our ethics protocol was a success-before people engage in research, they need to be fully informed about what the research is, what kinds of questions will be asked, how the data will be used, and what legal reporting requirements the researchers/focus group leaders must meet. If they are uncomfortable with participation, they are free to leave at any time. The Inuk counsellor who was a co-lead of the group talked with the participant and made sure she had access to counselling services if needed, and offered her food to take away with her.

The consent letter did not work well in the online survey portion of the research. Most people who visited the survey page did not start the survey. They were presented with a very lengthy consent letter, which was required by the Western University Non-Medical Research Ethics Board. Although a plain translation of the legalistic jargon was used and had been approved by the research ethics board, it was nevertheless law-oriented in tone because of the nature of the information required. The academic consent requirements were substantially the same for the online survey on social media use as for the much more highly personal and triggering issue of violence. There are thousands of online surveys on the Internet. Most of them are not academic surveys and have no preamble, so it is possible that potential participants were uncomfortable with having to sign the consent form.

\section{Conclusion}

The purpose of this article was to outline a successful process of Inuit participation in research and describe how the challenges of funding and group dynamics were met. A major challenge was how to deal with traumatic issues like violence in empowering rather than disempowering ways, and this is where Inuit engagement in developing the research process made the most significant difference. Pauktuutit, the community partner, initially agreed to collect information from Inuit youth about their experiences with violence but then showed discomfort on seeing the bald interview questions about sexual, physical, and psychological abuse. This discomfort was mirrored by Nunavut Sivuniksavut students, and also by Mamisarvik counsellors, who questioned, politely, why Inuit youth should be retraumatized in this way.

The focus of the Makilirit project thus shifted from documentation of violence to violence prevention, which was more conducive to the action goal of this participatory action research, i.e., to generate evidence for an outreach strategy to prevent violence among Inuit youth and to educate them about violence via social media. Only after a year of ongoing development and negotiation was the research design finalized and the formal academic research ethics application processed. Although not based in any Inuit region and not needing a localized research licence, the Makilirit project took about as long for pre-ethics consultation as a community-based project, as recommended in 
Negotiating Relationships with Inuit Communities: A Guide for Researchers (ITK and NRI 2007: 17).

The meeting of the violence prevention focus group resulted in gathering of relevant data: how Inuit youth understand high rates of violence in their communities; healthy and unhealthy coping mechanisms used by Inuit youth; what Inuit youth believe can realistically be done to reduce and eliminate violence; what they think other Inuit youth should know about violence; and how this knowledge should be communicated. It was also a reportedly positive experience for the participants. Because they thought all Inuit youth should have the opportunity to participate in such a focus group, the meeting also resulted in a template that could be used for other focus groups on the same theme. The social media survey resulted in new knowledge for Inuit organizations, which they could use to inform other efforts to reach out to young Inuit.

Many lessons were learned. There were several factors for success: a preexisting relationship between the researcher and partner organization; formal and informal time spent together, which deepened the relationship; choice of the research topic and approach by the Inuit organization; involvement of Inuit youth, healers, and elders; successful outreach to potential research participants through organizational contacts and the media; visibility of Inuit in leadership positions in the project; location of the research in a culturally safe space and inclusion of cultural practices; agreement on participation rules by the focus group ahead of time; verbal review of the consent letter, with time for questions and a clear opportunity for participants to withdraw from the research; and availability of counselling support for the violence prevention portion of the research. Funding was the biggest limitation. The limited funds available had an impact on where the research could be conducted, the languages of the research instruments, and the ability to gather the advisory committee members together in one room for development of trust and relationships. Other drawbacks were the lengthy, legalistic consent letter mandated by the academic research ethics board, the multiple and competing priorities for advisory committee members' time, and the difficulty in getting youth to the focus group meeting on a warm, sunny day.

The postdoctoral researcher was given a very small research budget. Although the budget can be used for knowledge transfer with Inuit youth through social media, it is insufficient to fund the type of social media outreach campaign which was the purpose of this participatory action research, which would have included visuals and videos as recommended by the Inuit youth research participants. At this time, no outreach has yet taken place, as it has not been funded. Because of staff turnover, Pauktuutit's project lead has moved on to other work, and no one is left at this organization with a personal stake in continuing the research. The project has left a legacy: a Facebook page (called Makilirit) that disseminates information about violence prevention and shares empowering stories about positive action by Inuit youth. Juno-Award-winning Inuk singer Tanya Tagaq has interacted with this page. Makilirit also has a Twitter handle that serves the same purpose. This social media presence, in the absence of funding for a targeted 
campaign based on the research results, has become a youth-focused social media presence for Pauktuutit's existing violence prevention materials. Hopefully, this article has provided a roadmap that academics can use to work in partnership with Inuit organizations by means of a participatory action research methodology that engages Inuit from the beginning to the end of the research process and beyond.

\section{Acknowledgments}

The author expresses her deep gratitude to Katharine Irngaut, who was Pauktuutit Abuse Prevention Manager at the time of the Makilirit project, and who was the community partner project lead. Without her efforts, personal contacts, and leadership, the project would not have succeeded. Many thanks for the discussions about the content of this article, and her review of it. The author would also like to thank the over 100 people who participated in one way or another in this project, including the research participants, for sharing their knowledge and experiences. Special thanks are due to Pauktuutit Executive Director Tracy O'Hearn. This study was funded through a CIHR (Canadian Institutes of Health Research) Institute of Aboriginal Peoples' Health postdoctoral fellowship, and was made possible by the participation of Pauktuutit Inuit Women of Canada, Mamisarvik Healing Centre, Nunavut Sivuniksavut, Tungasuvvingat Inuit, and the Ottawa Inuit Children's Centre.

\section{References}

BAUM, Fran, Colin MacDOUGALL and Danielle SMITH

2006 Participatory action research, Journal of Epidemiology and Community Health, 60(10): 854-857.

BRYDON-MILLER, Mary, Michael KRAL, Patricia MAGUIRE, Susan NOFFKE and Abu SABHLOK

2011 Jazz and the banyan tree: Roots and riffs on participatory action research, in Norman K. Denzin and Yvonna S. Lincoln (eds), Sage Handbook of Qualitative Research, 4th edition, Thousand Oaks, Sage.

CASTLEDEN, Heather, Paul SYLVESTRE, Debbie MARTIN and Mary McNALLY

2015 "I don't think that any peer review committee... would ever 'get' what I currently do": How institutional metrics for success and merit risk perpetuating the (re) production of colonial relationships in community-based participatory research involving Indigenous peoples in Canada, International Indigenous Policy Journal, 6(4): article 2.

CIHR, NSERC and SSHRC (CANADIAN INSTITUTES OF HEALTH RESEARCH, NATURAL SCIENCES AND ENGINEERING RESEARCH COUNCIL OF CANADA and SOCIAL SCIENCES AND HUMANITIES RESEARCH COUNCIL OF CANADA)

2010 Tri-Council Policy Statement: Ethical Conduct for Research Involving Humans, 2nd edition, Ottawa, Government of Canada, Interagency Secretariat on Research Ethics. 
FALS BORDA, Orlando

2001 Participatory (action) research in social theory: Origins and challenges, in Peter Reason and Hilary Bradbury (eds), Handbook of Action Research: Participative Inquiry and Practice, London, Sage: 27-37.

GALLOWAY, Tracey and Helga SAUDNY

2011 Inuit Health Survey 2007-2008: Nunatsiavut Community and Personal Wellness, Montreal, McGill University, Centre for Indigenous Peoples' Nutrition and Environment.

2012 Inuit Health Survey 2007-2008: Nunavut Community and Personal Wellness, Montreal, McGill University, Centre for Indigenous Peoples' Nutrition and Environment.

ITK (INUIT TAPIRIIT KANATAMI) and NRI (NUNAVUT RESEARCH INSTITUTE)

2007 Negotiating Relationships with Inuit Communities: A Guide for Researchers, Ottawa, Inuit Tapiriit Kanatami and Iqaluit, Nunavut Research Institute.

KEMMIS, Stephen and Robin McTAGGART

2000 Participatory action research, in Norman K. Denzin and Yvonna S. Lincoln (eds), Sage Handbook of Qualitative Research, Thousand Oaks, Sage: 567-605.

MACDONALD, Cathy

2012 Understanding participatory action research: A qualitative research methodology option, Canadian Journal of Action Research, 13(2): 34-50.

McTAGGART, Robin

1991 Principles for participatory action research, Adult Education Quarterly, 41(3): 168-187.

MORRIS, Marika and Claire CROOKS

2015 Structural and cultural factors in suicide prevention: The contrast between mainstream and Inuit approaches to understanding and preventing suicide, Journal of Social Work Practice, 29(3): 321-338.

MORRIS, Marika and Martha MUZYCHKA

2002 Participatory Research and Action: A Guide to Becoming a Researcher for Social Change / La recherche-action participative: Un outil pour le changement social! Ottawa, Canadian Research Institute for the Advancement of Women / Institut canadien de recherches sur les femmes.

NICKELS, Scot and Cathleen KNOTSCH

2011 Inuit perspectives on research ethics: The work of Inuit Nipingit, Études/Inuit/Studies, 35(1-2): 57-81.

O'NEIL, John D.

1986 Colonial stress in the Canadian Arctic: An ethnography of young adults changing, in C.R. Janes, R. Stall and S. Giford (eds), Anthropology and Epidemiology, Boston, Treidel Publishing: 249-274.

OWLIJOOT, Pelagie (in consultation with the Language and Culture Committee of Nunavut Arctic College)

2008 Guidelines for Working with Inuit Elders, Iqaluit, Nunavut Arctic College. 


\section{PAUKTUUTIT INUIT WOMEN OF CANADA}

2004 Abuse Prevention Services in Inuit Communities: Analytical Report, Ottawa, Pauktuutit Inuit Women of Canada.

2005 Research Report: Applying Inuit Cultural Approaches in the Prevention of Family Violence and Abuse, Ottawa, Pauktuutit Inuit Women of Canada.

2006 A National Strategy to Prevent Abuse in Inuit Communities and Sharing Knowledge, Sharing Wisdom: A Guide to the National Strategy, Ottawa, Pauktuutit Inuit Women of Canada.

2011 An On-the-Land Workshop Model for Inuit Women: Preventing Abuse through Supporting Women's Leadership, Ottawa, Pauktuutit Inuit Women of Canada.

2013a I'm Happy Because I'm Safe. Violence Prevention Campaign for Inuit Children. Communication Plan, Ottawa, Pauktuutit Inuit Women of Canada.

2013b A Community Story Workshop Model: An Intergenerational Healing Model, Ottawa, Pauktuutit Inuit Women of Canada.

LANEUVILLE, Pascale

2015 Bring Hope and Restore Peace: A Study Report on the Life and Concerns of Inuit Women in Nunavik, Inukjuak, Saturviit Inuit Women's Association of Nunavik and Quebec City, Université Laval, Community-University Research Alliance Leadership and Governance in Nunavut and Nunavik.

SMITH, Linda Tuhiwai

1999 Decolonizing Methodologies: Research and Indigenous Peoples, London and New York, Zed Books.

Statistics Canada

2010 Police-reported Crime in Inuit Nunangat, Ottawa, Statistics Canada.

2015 Aboriginal Population Statistics at a Glance, Ottawa, Statistics Canada.

WALLACE, Susan

2014 Inuit Health: Selected Findings from the 2012 Aboriginal Peoples Survey, Ottawa, Statistics Canada. 